\title{
Resistance to Spectinomycin Determined by R Factors of Various Compatibility Groups
}

\author{
By R. W. HEDGES \\ Bacteriology Department, Royal Postgraduate Medical School, \\ Du Cane Road, London, WI2 oHS
}

(Accepted for publication 20 April I972)

$\mathrm{R}$ factor mediated resistance to spectinomycin (an antibiotic aminoglycoside) was reported by Smith in 1967 . He observed that several $R$ factors (all of which conferred streptomycin resistance on their hosts) also conferred spectinomycin resistance. He found that several of the spectinomycin-resistant bacteria carried $f i^{+} \mathrm{R}$ factors but that in at least one strain the resistance was determined by an $f^{-} \mathrm{R}$ factor (Smith, 1967). Benveniste, Yamada \& Davies (I970) showed that $\mathrm{R}$ factor mediated resistance to both streptomycin and spectinomycin was conferred by streptomycin/spectinomycin adenylate synthetase. $\mathrm{R}$ factor mediated resistance to streptomycin (without spectinomycin resistance) was shown to be due to production of streptomycin phosphotransferase (Ozanne, Benveniste, Tipper \& Davies, 1969).

In a recent review, Davies, Brzezinska \& Benveniste (I97I) conclude that these two enzymes were responsible for all R-mediated resistance to streptomycin or spectinomycin investigated in their laboratory or in other laboratories studying inactivation of aminoglycosides by the Enterobacteriaceae. If this conclusion is generally valid we can identify the enzyme responsible for inactivation of streptomycin by testing for coincident spectinomycin resistance.

The resistance patterns to streptomycin and spectinomycin determined by $\mathrm{R}$ factors of various compatibility groups are reported here.

\section{METHODS}

Bacteria. Escherichia coli K I2, J53 met pro (Clowes \& Hayes, I968).

$R$ factors. Listed in Table I.

Resistance determination. Resistances to streptomycin and spectinomycin were detected by streaking over nutrient agar ditches containing streptomycin ( $15 \mu \mathrm{g} / \mathrm{ml})$ or spectinomycin $(50 \mu \mathrm{g} / \mathrm{ml})$.

\section{RESULTS AND DISCUSSION}

Resistance to streptomycin and spectinomycin of $\mathrm{J} 53$ carrying $\mathrm{R}$ factors of various compatibility groups are listed in Table $\mathrm{I}$.

The $f^{+} \mathrm{R}$ factors tested all gave resistance to both streptomycin and spectinomycin (or to neither). Thus, presumably all inactivate these aminoglycosides by adenylation. Smith (I967) reported some bacteria carrying $f^{+}{ }^{+} \mathrm{R}$ factors resistant to streptomycin but not to spectinomycin. Possibly, the streptomycin resistance of these strains was determined by covert $f^{-} \mathrm{R}$ factors also present in the bacteria (see Romero \& Meynell, 1969).

All but one of the I-like $\mathrm{R}$ factors tested failed to confer spectinomycin resistance. We, therefore, believe that the plasmids of this group that confer streptomycin resistance do so by phosphorylation. R62 is an unusual R factor since it is a member of the I-like compatibility group, being incompatible with R I44 (Hedges \& Datta, unpublished) produces I-like 
Table I. Resistance to spectinomycin conferred by $R$ factors which determine streptomycin resistance

\begin{tabular}{|c|c|c|c|c|}
\hline \multirow[b]{2}{*}{$\begin{array}{c}\text { Compatibility } \\
\text { group }\end{array}$} & \multicolumn{3}{|c|}{ Phenotype of $\mathrm{J} 53$ carrying the plasmid } & \multirow[b]{2}{*}{ Reference } \\
\hline & $\begin{array}{c}f i \\
\text { character }\end{array}$ & $\begin{array}{l}\text { Resistant to } \\
\text { streptomycin and } \\
\text { spectinomycin }\end{array}$ & $\begin{array}{l}\text { Resistant to } \\
\text { streptomycin } \\
\text { but sensitive to } \\
\text { spectinomycin }\end{array}$ & \\
\hline \multirow[t]{2}{*}{$F_{I I}$} & $f^{+}$ & $\begin{array}{l}\mathrm{R}_{\mathrm{I}}, \mathrm{R}_{2}, \mathrm{R}_{28}, \mathrm{R}_{52}, \\
\mathrm{R}_{73}, \mathrm{R}_{77}, \mathrm{R}_{82}, \\
\mathrm{R}_{114}, \mathrm{R}_{192}, \mathrm{R}_{196}, \\
\mathrm{R}_{312}\end{array}$ & None & Lawn et al. (1967) \\
\hline & & $\mathrm{R} 222$ & & Watanabe et al. (1964) \\
\hline \multirow[t]{2}{*}{ I } & $f^{+}$ & R62 & & Lawn et al. (1967) \\
\hline & $f^{-}$ & & $\begin{array}{l}\text { R64, R92, Ri63, } \\
\text { R302, R306, R307, } \\
\text { R308, R313r }\end{array}$ & Lawn et al. (1967) \\
\hline \multirow[t]{4}{*}{$\mathrm{N}$} & $f^{-}$ & $\mathrm{N}_{3}, \mathrm{R}_{15}, \mathrm{R}_{4} 6$ & & Datta \& Hedges (I97I) \\
\hline & & RM98 & & Khatoon \& Iyer (197I) \\
\hline & & $\mathrm{R}_{132}, \mathrm{R}_{48}$ & $\mathrm{R}_{348 \mathrm{~N}, \mathrm{R} 269 \mathrm{~N}}$ & Hedges (1972) \\
\hline & & $\begin{array}{l}\mathrm{R}_{390,} \mathrm{R}_{395}, \mathrm{R}_{396} \\
\mathrm{R}_{398,} \mathrm{R}_{400}\end{array}$ & & $\begin{array}{l}\text { Coetzee, Datta \& } \\
\text { Hedges (I972) }\end{array}$ \\
\hline $\mathrm{W}$ & $f^{-}$ & $\mathrm{S}-\mathrm{a}, \mathrm{RA}_{3}, \mathrm{RA}_{4}$ & None & Hedges \& Datta (197I) \\
\hline $\mathrm{T}$ & $f^{-}$ & $\mathrm{R} 402$ & $\mathrm{R}_{40 \mathrm{I}}$ & Coetzee et al. (1972) \\
\hline Unclassified & $f^{-}$ & & $\mathrm{R}_{300}, \mathrm{R}_{305}, \mathrm{R}_{3} \mathrm{IO}_{0}$ & Lawn et al. (1967) \\
\hline
\end{tabular}

pili and yet is $\mathrm{fi}^{+}$. Unlike other I-like $\mathrm{R}$ factors it confers resistance to ampicillin (Lawn, Meynell, Meynell \& Datta, 1967). This plasmid probably contains genetic information derived from an F-like plasmid and the streptomycin/spectinomycin resistance determinant may be part of this heritage.

Most $\mathrm{N}$ plasmids which confer resistance to streptomycin also confer spectinomycin resistance. There are, however, two exceptions (see Table $\mathrm{I}$ ).

Three R factors, R $300, \mathrm{R}_{305}$ and 310 , confer resistance to streptomycin but not to spectinomycin. These three $f_{i}$ plasmids, all carrying streptomycin and sulphonamide resistances, are compatible with $\mathrm{N}$ and with I-like $\mathrm{R}$ factors (unpublished data). They may all be members of a single compatibility group but the identity of their resistances makes it impossible to test this point. All plasmids of the W group which conferred streptomycin resistance also conferred spectinomycin resistance.

Like the $\mathrm{N}$ group, the $\mathrm{T}$ group includes plasmids showing both types of streptomycin resistance.

\section{REFERENCES}

Benveniste, R., Yamada, T. \& Davies, J. (1970). Enzymatic adenylation of strept mycin and spectinomycin by R-factor-resistant Escherichia coli. Infection and Immunity I, I09-II6.

Clowes, R. C. \& Hayes, W. (1968). Experiments in Microbial Genetics. Oxford: Blackwells Scientific Publications.

Coetzee, J. N., Datta, N. \& Hedges, R. W. (1972). R factors from Proteus rettgeri. Journal of General Microbiology.

Datta, N. \& Hedges, R. W. (1971). Compatibility groups among $f^{-}$R factors. Nature, London 234, 222-223.

Davies, J., Brzezinska, M. \& Benveniste, R. (I971). R factors: Biochemical mechanisms of resistance to aminoglycoside antibiotics. Annals of the New York Academy of Sciences 182, 226-233. 
HEDGES, R. W. (1972). Phenotypic characterization of $f^{-}$R factors determining the restriction and modification hsp II specificity. Molecular and General Genetics I15, 225-233.

Hedges, R. W. \& DatTA, N. (I97I). $f^{-}$R factors giving chloramphenicol resistance. Nature, London 234, 220-22I.

KhAtoon, H. \& IYeR, R. V. (I97I). Stable coexistence of R $f^{-}$factors in Escherichia coli. Canadian Journal of Microbiology $\mathbf{1 7}, 669-675$.

Lawn, A. M., Meynell, E., Meynell, G. G. \& Datta, N. (1967). Sex pili and the classification of sex factors in the Enterobacteriaceae. Nature, London 216, 343-346.

OzAnne, B., Benveniste, R., Tipper, D. \& Davies, J. (I969). Aminoglycoside antibiotics: inactivation by phosphorylation in Escherichi coli carrying R factors. Journal of Bacteriology 1oo, I I 44-I I 46.

Romero, E. \& MeYNell, E. (I969). Covert $f^{-} \mathrm{R}$ factors in $f^{+} \mathrm{R}^{+}$strains of bacteria. Journal of Bacteriology 97, $780-786$.

Sмiтh, D. H. (1967). R factor-mediated resistance to new aminoglycoside antibiotics. Lancet i, 252-254.

Watanabe, T., Nishida, H., Ogata, C., Arai, T. \& Sato, S. (1964). Episome-mediated transfer of drug resistance in Enterobacteriaceae. VII. Two types of naturally occurring R factors. Journal of Bacteriology $88,716-726$. 